\title{
LA IMAGEN VIRIL DE PASIONARIA. LOS SIGNIFICADOS SIMBÓLICOS DE DOLORES IBÁRRURI EN LA II REPÚBLICA Y LA GUERRA CIVIL (1)
}

\author{
MIREN LLONA \\ Universidad del País Vasco/Euskal Herriko Unibertsitatea UPV/EHU \\ miren.llona@ehu.eus
}

(Recepción: 15/12/2015; Revisión: 07/04/2016; Aceptación: 23/05/2016; Publicación: 02/12/2016)

1. INTRODUCCIÓN.-2. LA EMANCIPACIÓN DE DOLORES IBÁRRURI: EL FRUTO DE DOS RUPTURAS.-3. LA EXPLOSIÓN PÚBLICA DE PASIONARIA.-4. LA GUERRA CIVIL Y LA CONVERSIÓN DE PASIONARIA EN UN SÍMBOLO NACIONAL ESPAÑOL.-5. BIBLIOGRAFÍA

\begin{abstract}
RESUMEN
A partir del análisis de la figura de Pasionaria, este artículo muestra el significado cambiante de la feminidad durante el primer tercio del siglo xx y, especialmente, en el contexto abierto por la II República y la Guerra Civil. Su condición de mujer del pueblo y posteriormente su posición excepcional como mujer dirigente del Partido Comunista favorecieron la identificación de Dolores Ibárruri con valores atribuidos genéricamente a la virilidad. Sin embargo, y conforme la Guerra Civil avanzó, en el bando republicano se produjo una reorganización del orden de género en torno a la figura de la madre que colmó de legitimidad los significados de la feminidad. La propia imagen de Dolores Ibárruri cambió siendo presentada entonces como una madre sacrificada. Esto contribuyó a reforzar el activismo de las mujeres en la retaguardia republicana dentro del papel de madres pero, a la vez, consolidó el papel heroico de los hombres republicanos reafirmando su hombría como combatientes. Asimismo, la representación de Pasionaria como una madre heroica contribuiría a consolidar la II República como la más auténtica de las expresiones nacionales españolas.
\end{abstract}

(1) Deseo agradecer a Nerea Aresti sus comentarios y su generosa ayuda en la realización de este trabajo. Este artículo se inscribe en el marco del Grupo de Investigación Universitaria de la UPV/EHU titulado «La experiencia de la sociedad moderna en España (1870-1990)» GIU14/22: UFI11/27 y HAR2012-37959-C02-01. 
Palabras clave: género; mujeres; Dolores Ibárruri; Pasionaria; Guerra Civil española; diferencia sexual.

\title{
THE VIRILE IMAGE OF PASIONARIA. THE SYMBOLIC MEANING OF DOLORES IBARRURI IN THE II REPUBLIC AND THE CIVIL WAR
}

\begin{abstract}
This article analyzes the changing meaning of femininity in the first quarter of the 20th Century in Spain, by looking at the political role of the communist leader Pasionaria. Focusing on the image of Dolores Ibárruri as a woman of the people first and then as the unique woman leader of the Communist Party, this article draws attention to how close her image was to masculine values. However, as the Civil War progressed, her symbolic meaning changed. Republicans put the stress on the figure of the mother as the core of femininity in an attempt to preserve gender order. Dolores Ibárruri then became a caring and self-sacrificing mother. All this reinforced the activism of republican women as mothers in the rearguard and, at the same time, this process reinforced the heroic role of republican men as combatants. The representation of Pasionaria as a heroic mother also contributed to consolidate the II Republic as the most authentic of the Spanish national expressions.
\end{abstract}

Keywords: gender, women; Dolores Ibárruri; Pasionaria; Spanish Civil War; sexual difference.

$* \quad * \quad *$

\section{INTRODUCCIÓN}

Durante el primer tercio del siglo Xx coexistieron diferentes formas de entender la feminidad y de construir la subjetividad femenina y, por ello, consideramos que se pueden encontrar identidades femeninas híbridas, compuestas por rasgos de la feminidad más tradicionales mezclados con otros más abiertamente modernos. En general, lo considerado socialmente respetable para las mujeres en aquellos años se traducía en identidades femeninas más ambiguas de lo que a menudo estamos dispuestos a admitir y que coincidían menos de lo esperado con el estereotipo de la diferencia sexual. Mi trabajo se acercará a ese escenario diverso con el fin de comprender, en concreto, las condiciones de posibilidad que rodearon la vida de Dolores Ibárruri y, asimismo, analizar los componentes con los que contó para construirse subjetivamente como mujer y como dirigente comunista, pero también para llegar a convertirse en un símbolo nacional republicano. Partiendo del análisis de su biografía individual, mi intención es doble: por un lado, llegar a comprender al sujeto histórico, tanto el 
significado de los diferentes materiales identitarios de los que se valió como mujer, como el conjunto de decisiones y circunstancias que hicieron posible su ascenso político, su relevancia social como militante del Partido Comunista de España y, ya en el contexto de la guerra, coincidiendo con el progresivo carácter nacional que adoptó la contienda en el bando republicano, interpretar la identificación estereotipada de su figura con la imagen de la madre. Por otro lado, y a través del estudio de un caso individual, espero encontrar resonancias de la memoria colectiva femenina de una época que permitan acercarse a la experiencia y a la subjetividad de las mujeres trabajadoras de los años veinte y treinta.

Desde la perspectiva de hoy, la figura de Dolores Ibárruri ha quedado vinculada a la imagen de la madre. Diferentes circunstancias han contribuido a ello y el hecho de que las jóvenes generaciones se hayan referido a ella como «la madre», dada su larga trayectoria como dirigente comunista, no ha sido un dato intrascendente (2). En todo caso, un factor definitivo que ha contribuido a reforzar su imagen actual como madre ha sido el carácter de su propia autobiografía, El único camino. Los especialistas que han trabajado su figura coinciden en señalar que Dolores Ibárruri diseñó su autobiografía en torno a la figura de la madre: en la primera parte de su obra se describe a sí misma como la esposa de un minero y madre sacrificada de seis hijos/as; en la segunda parte, como madre combativa de la revolución. En toda ella, de forma deliberada, Dolores Ibárruri se representa a sí misma a través de la figura de la «madre coraje» (3).

Pero la imagen de madre sacrificada, no solo fue cultivada por ella misma, también fue la representación de Pasionaria que el Partido Comunista fomentó como símbolo nacional y que salió reforzada de la propia Guerra Civil española. Las imágenes de Pasionaria creadas por poetas y artistas han contribuido decisivamente a hacer de Dolores Ibárruri un icono que ha sobrepasado al sujeto histórico, pero que también ha explotado su imagen como madre. A partir de la representación de Pasionaria como madre sacrificada de todos los españoles durante la Guerra Civil, Dolores Ibárruri fue convertida en un símbolo, en una personificación de los ideales democráticos y en un mito universal que ha llegado a trascender el conflicto histórico de la Guerra Civil española (4). Por todo ello, a la hora de analizar la figura de Dolores Ibárruri, la imagen de la madre moldea toda nuestra comprensión de Pasionaria, tal y como plantea la historiadora Carrie Hamilton (5).

Mi objetivo a lo largo de este artículo es deconstruir los significados de esas representaciones y de esa imagen estereotipada, comprobando hasta qué punto

(2) CRUZ (1999): 191.

(3) Blanco (1986): 435; Hamilton (2001): 17; Herrmann (1998): 197, Yusta (2009): 36.

(4) Dellinger (2014): 297, 299; VÁzQuez Montalbán (1995): 347-367. Ginard i Féron (2013): 199-204.

(5) HAMILTON (2001): 17. 
durante los años veinte y treinta, el sentido del significante madre y del significante mujer no fue estable y dio cobertura a formas no convencionales de construir la subjetividad femenina. Una de las representaciones femeninas con la que Dolores Ibárruri se sintió más identificada a lo largo de su vida fue la de mujer del pueblo (6). Entiendo que se sintió cómoda dentro de esa categoría porque la idea de mujer del pueblo incorpora una combinación de rasgos femeninos, como veremos, más amplia que la dictada por la feminidad normativa propia de la diferencia sexual. Esa forma distinta de entender la feminidad le permitió habitar su cuerpo de mujer de forma menos rígida, dándole la posibilidad de transitar por el mundo en él sin respetar los límites impuestos a su sexo, a través de una identidad femenina fuerte y viril.

Al principio del siglo xx, el conjunto de atributos que cabía en la idea de mujer del pueblo era una amalgama de significados entre los que la dicotomía Eva/María de la tradición católica es esencial para su comprensión. Desde esa perspectiva, las mujeres, percibidas como las responsables del pecado original, podían llegar a expiar su condición por medio del fortalecimiento de su espíritu a través del sacrificio, del trabajo y de la abnegación. Por ese camino, era posible alcanzar el papel representado por María, expresión máxima de la pureza femenina. Algunas advocaciones de la Virgen, como la de la Dolorosa, la equiparaban en excelencia y poder con la propia figura divina de Jesucristo. De alguna manera, el héroe de la redención de la humanidad podía llegar a compartir protagonismo con su madre, una figura femenina. Así, en el imaginario cultural católico, la condición de las mujeres, a través del sacrificio y del dolor, podía acercarse a significados que la identificaban con la virtud y la santidad viriles representadas por Jesucristo. Nerea Aresti sostiene que el concepto viril en algunos contextos y momentos históricos tiende a identificarse con elevación moral incluso para las mujeres (7). Dolores Ibárruri participó de ese universo cultural católico. Ella misma ha confirmado las profundas raíces católicas sobre las que se construyó su infancia y su vida familiar. De hecho, es posible establecer un vínculo no casual entre su elección del nombre Pasionaria y su aspiración a alcanzar, a través del mismo, una identificación con la virtud y la santidad viriles (8).

La figura de la mujer del pueblo recogía esos significados culturales de tradición católica y, en esa medida, contribuía a legitimar entre las clases populares y de origen trabajador, un prototipo de feminidad caracterizado por el sacrificio, la abnegación, el trabajo y la fortaleza. El contexto minero vizcaíno de

(6) VÁZquez Montalbán (1995): 59; CAMino e IbÁRruRi (2006): 130-32; PAMiés (1977): 89.

(7) ARESTI (2014b): 161. Asimismo, existe también una caracterización legendaria de las mujeres vascas como fuertes, vigorosas, austeras e incluso rudas, ARESTI (2014a): 285, de la que Ibárruri, por su origen vasco, también se haría heredera.

(8) Como Rafael Cruz ha puesto de relieve, las resonancias simbólicas del nombre de Pasionaria remiten a una identificación entre los sufrimientos padecidos por Jesús y los de su Madre María, CRUZ (1999): 55. 
comienzos del siglo Xx del que proviene Dolores Ibárruri, además de participar de ese imaginario relativo a la mujer del pueblo, era un universo cultural donde el valor de la figura del minero era enorme, tanto por la importancia que el obrero había adquirido como mano de obra preferente y casi exclusiva de la explotación de las minas de hierro, como por su relevancia en la naciente lucha de clases, y embrión del sujeto político que hizo posible la formación de la primera toma de conciencia obrera (9). En ese entorno, el protagonismo que adquirió la imagen del minero es incontestable, y las mujeres participaron también de una retórica épica de la mina por la que a la figura del héroe minero se le atribuían unos rasgos de virilidad idealizados, caracterizados por la valentía para afrontar el trabajo duro, el coraje para soportar las condiciones de explotación y la entereza para organizarse. Todos esos méritos y valores atribuidos a la virilidad minera podían ser, tanto por los hombres como por las mujeres del entorno minero, admirados (10). Cuando eran emulados también por las mujeres, se podían llegar a constituir identidades femeninas híbridas que incorporaban a la subjetividad propia de su sexo ideales de la virilidad minera. Así, desde un cuerpo femenino y en un entorno como el que dio vida a Dolores Ibárruri, era posible llegar a establecer grados significativos de identificación con toda una serie de rasgos atribuidos a la masculinidad, favoreciendo la construcción de subjetividades femeninas más heterogéneas. Shirley Mangini habla de la «sedicente virilidad» de Pasionaria lo que, según esta autora, era considerado un aspecto positivo de su personalidad por sus defensores, tanto como fue una cualidad siniestra y anormal para sus detractores (11).

Desde mi punto de vista, la figura de la mujer del pueblo, con la que Dolores Ibárruri jamás dejó de identificarse, y el orgullo minero de clase que compartía le permitieron incorporar un conjunto de rasgos de carácter viril a su definición subjetiva. La elevación moral que aportó el sentido masculino de algunos de sus actos y principios le dio poder en diferentes circunstancias,

(9) ARbaiza (2015): 65.

(10) Por ejemplo la identidad de Elisa Antón, una mujer más joven que Dolores Ibárruri, pero nacida en el mismo entorno minero que ella y que se sintió orgullosa cuando su padre la nombró 'Paco el minero': «Los mineros, ¡cuánto han luchao aquellos siempre!, porque era muy duro aquello, tú sabes lo que es arrancar las piedras de la mina, con picos, con azadas, con pilos, que se rompían las rocas, eso era durísimo. Mi vida ha sido mucho trabajo pero, lo del minero es más duro, eso no lo hace cualquiera ¿eh? [...]. Yo conocía el mineral y el carbonato a la legua, la chirta que llamábamos, por eso me llamó 'Paco el minero', y me lo dijo: “aquí está Paco el minero", el que me quiera preguntar algo que me lo diga (pausa)...», Elisa Antón (extracto). Entrevista realizada por Miren Llona 12-11-2002 y depositada en AHOA, Ahozko Historiaren Artxiboa. Elisa Antón nació en 1915, en el poblado minero de Barrionuevo en La Arboleda (Bizkaia). Juliana, la madre, había llegado a La Arboleda procedente de Burgos en los albores del siglo XX a la edad de trece años. Ramón, el padre, vino con veinte años también de Burgos. Juliana tuvo catorce alumbramientos de los cuales salieron adelante 7 hijos/as. El padre fue minero y la madre pupilera. Elisa fue la cuarta hija de este matrimonio y ayudó desde su infancia a la supervivencia familiar.

(11) MANGINI (1997): 51. 
contribuyendo a crear una imagen pública de mujer fuerte; en otros momentos, sin embargo, como veremos, la figura de la madre se reafirmará como eje de su representación subjetiva, saturando todo el significado de ser mujer. En todo caso, fue la ambivalencia de los significados de la feminidad la que permitió a Ibárruri transcurrir por un itinerario vital complejo en el que, unas veces, su integridad de militante comunista se vería reforzada a pesar de ser mujer y, otras, su legitimidad como líder político de masas se vería incrementada gracias a su imagen como madre.

\section{LA EMANCIPACIÓN DE DOLORES IBÁRRURI: EL FRUTO DE DOS RUPTURAS}

La conversión de Dolores Ibárruri en una líder política de masas fue el resultado de dos rupturas. La primera supondrá el alejamiento del catolicismo y su conversión a las ideas del socialismo y al entusiasmo por la Revolución de Octubre: es el nacimiento de Pasionaria. La segunda ruptura supondrá su separación de Julián Ruiz, su marido y el padre de sus hijos/as; también supondrá el abandono de Vizcaya y de la cuenca minera y su traslado a Madrid. Esta segunda ruptura significó para Dolores Ibárruri poner por delante su activismo militante a sus obligaciones familiares como esposa y, también en cierta medida, como madre. Ibárruri se convirtió en una mujer emancipada de ataduras convencionales, y sus decisiones, en el plano político y personal, tuvieron más una impronta convencionalmente masculina que maternal.

Analizaremos ambas rupturas a través de dos documentos autobiográficos de carácter muy distinto. El primero, redactado por ella en 1935 en la Unión Soviética, cuando es una dirigente comunista entregada a una causa emergente como es la construcción del PCE en España, es un documento interno, una semblanza de sí misma para poner en conocimiento de la Internacional Comunista (IC) su perfil como activista comunista (12). El segundo es su autobiografía El único camino, redactada a finales de los años cincuenta, en un momento de declive como dirigente y de necesidad por recuperar autoridad en la dirección del PCE (13). Combinaremos en nuestro análisis ambos relatos.

(12) Escrito realizado por Dolores Ibárruri en julio de 1935, en el viaje realizado con José Díaz al VII Congreso de la IC, de cuyo secretariado fue nombrada miembro suplente. Documento archivado en el Archivo Histórico del PCE 13/1. 1

(13) La autobiografía fue escrita en los años cincuenta y publicada en 1962, veintitrés años después de su exilio y una vez que había dejado de ser la secretaria general del Partido Comunista y se había convertido en presidenta del mismo, un cargo honorífico creado especialmente para ella en el VI Congreso del PC en 1960. Diferentes autores/as convienen en que Ibárruri construyó a la protagonista de su autobiografía de forma consciente y coherente, con el fin de consolidar su liderazgo a los sesenta y siete años de edad. Y lo hizo manteniendo una estrategia de silencio respecto a las intrigas postestalinistas y a las luchas por el poder en el PC, tanto como silenciando su relación sentimental con Francisco Antón. Por otro lado, su otra estrategia fue reforzar el 
En el documento de 1935, como rasgo demostrativo de su autenticidad obrera, Dolores Ibárruri comienza describiendo sus orígenes mineros (14). Posteriormente, relata cómo se casó, contra la voluntad de su familia, con un obrero socialista activo y comprometido. Ese acontecimiento clave es puesto de relieve como el comienzo de una rebeldía que le conducirá al abandono del catolicismo y, utilizando sus propias palabras, a la apertura «en mi conciencia de una perspectiva completamente nueva» que es la que le proporcionaría el conocimiento de las ideas socialistas. En esos primeros apuntes, hasta su incorporación en 1918 a las filas del Partido Socialista, Dolores Ibárruri describe lo que fue su activismo político como hija, hermana y esposa de un minero, en cierta medida actuando como se esperaba de una mujer dentro de los cánones de la respetabilidad obrera. En 1919, sin embargo, se produce su primer acto de afirmación como militante, coincidiendo con la publicación de unos artículos en el Minero Vizcaíno «de defensa entusiasta» de la Revolución Rusa, y firmados ya con el nombre de «Pasionaria», apelativo «que muy pronto se hizo popular en toda la zona minera», como reconoce la propia Ibárruri en su escrito (15). La creación de ese alter ego constituyó un hecho de capital importancia porque le permitió preservar su anonimato (16). Recordemos que Dolores Ibárruri empezó a construirse como militante socialista al margen de su marido y a pesar de ser mujer. La ambigüedad del nombre Pasionaria le permitió, en aquel mundo hostil de la acción política, realizar un activismo de corte masculino siendo mujer y, también posteriormente, contribuir en calidad de madre a su legitimación como líder político femenina.

En 1920 la ruptura con el Partido Socialista y la adhesión a la III Internacional es ya un acontecimiento en el que Pasionaria se describe a sí misma como un sujeto con opinión política y agencia individual: «Les envié mi adhesión entusiasta y con mi compañero y otros camaradas que pensaban igual conseguimos que la Agrupación Socialista de Somorrostro [...] ingresara en el Partido Comunista recién creado». A partir de ese momento, como ella misma reconoce, «empecé a hacer vida de partido [...] colaboré en todos los periódicos del partido» y, como consecuencia de todo ello, entre 1920 y 1930 Ibárruri pasó de

discurso de la maternidad. IBÁRRURI (1972) [1962]; PAMIÉs (1977): 67; VÁZQUEZ MoNTALBÁN (1995): 45; HERRMANN (1998): 185; GINARD i FÉRON (2013): 197.

(14) Rafael Cruz ha señalado que los dirigentes del PC resaltaron una serie de cualidades en la persona de Dolores Ibárruri que eran coincidentes con las virtudes atribuidas por ellos al pueblo: humildad de origen; rebeldía para superar los obstáculos; la prioridad de la lucha por la justicia; el sufrimiento, similar al Mesías que sacrificó su vida por los demás; la pureza y distancia del abuso de poder, Cruz (1999): 131. El hecho de que, en cierta medida, sea este el hilo argumental que Ibárruri utiliza para realizar su semblanza autobiográfica es indicativo de que conocía bien las condiciones de respetabilidad de la cultura comunista y que probablemente las compartía.

(15) IBÁRRURI (1935).

(16) CRUZ (1999): 54 
ser miembro del Comité Regional de Vizcaya a miembro del Comité Central del Partido y a ser requerida su presencia en Madrid (17).

En su semblanza como militante Ibárruri trata de destacar ante la IC aquellos hitos que la elevan moralmente por su carácter viril, lo que vendría a demostrar hasta qué punto la construcción de un perfil oficial de militante comunista exigía un comportamiento en el que su peculiaridad como mujer se mostrara irrelevante. Así ocurre en la parte en que relata su elección como delegada al Congreso de París en 1927, que exigió pasar de forma clandestina e ilegal por la frontera, iniciativa que, finalmente, fue cortocircuitada por los carabineros, pero donde se ponían en evidencia su entereza y arrojo militantes, a semejanza de cualquier camarada masculino. De la misma manera, en esos apuntes autobiográficos de 1935, sus detenciones y la valoración política de las mismas son un tema importante (18). No en vano, los arrestos y las encarcelaciones eran habitualmente percibidas como muestras de sacrificio y de entrega al partido. Desde esa perspectiva, Ibárruri no dudó en hacerlas valer en su perfil militante para incrementar su autoridad y su prestigio (19). El documento finaliza con la descripción de su actividad política en las organizaciones de masas y, especialmente, de su labor en la creación y desarrollo de los Comités de Mujeres contra la Guerra y el Fascismo.

Asimismo, ese documento que Dolores Ibárruri elaboró para la IC constituye una historia de invisibilidad de otro conjunto de experiencias intensas que Ibárruri vivió durante aquellos mismos quince años, especialmente todas las relativas a lo que podríamos considerar su vida personal y familiar. Entre 1916 y 1929 Dolores Ibárruri tuvo seis hijos/as de los que solo sobrevivieron dos (20). En octubre de 1931, cuando Ibárruri, miembro ya del Comité Central, se trasladó a Madrid a trabajar en la redacción de Mundo Obrero, se llevó con ella a Rubén y a Amaia, los dos únicos hijos supervivientes, la demostración viva de los estragos causados por la mortalidad infantil en la zona minera de Vizcaya. ¿Cómo pudo Pasionaria sobrellevar y compaginar sus sucesivos embarazos, partos y crianzas con su activismo político?

A pesar de que su experiencia como madre quedó oculta para el partido en su documento de 1935, en El único camino es posible explorar la experiencia

(17) IBÁRRURI (1935).

(18) IBÁRRURI (1935).

(19) Vázquez Montalbán coincide en señalar que la actitud de Dolores Ibárruri durante sus encarcelamientos forma una de las bases de su prestigio combatiente, VÁZQUEZ MONTALBÁN (1995): 62. Entre 1931 y 1935 Dolores Ibárruri estuvo detenida cinco veces. Su permanencia en la cárcel fue a veces de días o de pocas semanas, y otras veces su estancia fue más prolongada. En 1932 pasó 11 meses entre la cárcel de Quiñones de Madrid y la de Larrínaga de Bilbao.

(20) En 1916 Dolores Ibárruri dio a luz a su primera hija, Esther. En 1920, el mismo año que fue nombrada miembro del Comité Provincial de Vizcaya, nació su segundo hijo, Rubén, y murió Esther. De las trillizas que nacieron en 1923, murió en ese mismo año Amagoya y en 1925 Azucena. Amaia sobrevivió. Finalmente, en 1929 nació y murió Eva, su última hija. 
emocional causada por la pérdida de los hijos/as. Ibárruri sentencia: «Es difícil medir las penas que caben en el corazón de una madre y la capacidad de resistencia al dolor que hay en cada corazón maternal» (21). Como buena mujer del pueblo, Ibárruri exalta la capacidad de sufrimiento de las mujeres fuertes, de las madres sacrificadas. Pero no es solo eso, poner en relación la vehemencia de su militancia política durante aquella década de los años veinte y la intensidad de su experiencia como madre, nos permite comprender hasta qué punto Ibárruri volcó la rebeldía provocada por la pérdida de sus hijos/as y por la decepción de su experiencia matrimonial en el ímpetu revolucionario y en la esperanza de un futuro mejor asociada a él. Así, su realidad como mujer y madre, en vez de alejarla de la actividad política, le ayudó a revalidar su compromiso militante, lo que le permitió superar cuestiones prácticas que hubieran podido entorpecer su activismo en el partido: sobreponerse al dolor, compaginar el mundo doméstico con la militancia y, en última instancia, priorizar el activismo político a sus obligaciones domésticas. Con todo ello se fraguó una subjetividad femenina alejada de los convencionalismos que sometían a las mujeres a la resignación. Irene Falcón recuerda que Ibárruri siempre se remitía a su propia experiencia para explicar a las mujeres cómo podían llegar a participar activamente en la política:

Madrugando y trasnochando. Acostumbraba a mis hijos a no dormir por la tarde para que por la noche me dejaran tranquila y poder asistir a las reuniones. Después cuando fueron un poco mayores los acostumbré a quedarse solos y a no tener miedo y a ayudarme en las faenas de la casa. ¿Que esto es duro? Es verdad, y a mí me dolía en el alma, como me dolía nuestra vida. Pero era preciso hacerlo y lo hacía (22).

La importancia y necesidad de promocionar la incorporación de las mujeres a la lucha política fue un aprendizaje que Pasionaria trasladó al Partido Comunista, que defendió dentro de la organización y que transmitió públicamente a lo largo de su trayectoria política, aun a sabiendas de que el mensaje resultaba subversivo y trastocaba el orden sexual instalado en el partido, profundamente refractario a las demandas de género (23). En realidad, la denuncia de Dolores Ibárruri apuntaba a la desigualdad de las relaciones de género en el hogar obrero

(21) IBÁRRURI (1972): 120.

(22) FALCón (1996): 207.

(23) Irene Falcón denuncia el ambiente machista que existía dentro del Partido, ibidem: 94. Nash también señala que «Ibárruri acusó a los hombres de su partido de caer en contradicciones graves en sus relaciones con el sexo femenino. Lejos de practicar la igualdad [...] atribuían a la mujer una inferioridad frente a ellos. Ibárruri acusa de machismo a los comunistas», Nash (1981): 178. Cruz destaca la importancia marginal de las cuestiones femeninas en el partido y la denuncia realizada por Ibárruri en 1933: «Son nuestros propios camaradas los que se oponen a que la mujer intervenga en la vida política y social» en Cruz (1999): 91. Para Alemania, Gruber y Graves también destacan que el Partido Comunista Alemán, «Never fundamentally challenged the gender división of labor in the household, workplace or public arena», GRUBER y GRAVES (1998): 18. 
y a la organización doméstica familiar dentro del mismo. Ibárruri, especialmente, quería poner en evidencia la costumbre de los hombres, y también de los militantes obreros, de frecuentar la taberna mientras las mujeres se quedaban bregando «con los hijos, con la miseria, y con todo lo que había en casa». Durante más de una década de convivencia matrimonial con Julián Ruiz, el significado que Dolores Ibárruri atribuyó a ser esposa y madre quedó asociado a la idea de servicio y de esclavitud: «En el hogar la mujer se despersonaliza, se entrega por la fuerza de la necesidad al sacrificio [...] apencar con toda clase de servicios [...] hasta anularse por completo [...]» (24). Cuando en 1931 Dolores Ibárruri se trasladó a Madrid con sus dos hijos también abandonó para siempre a su marido. Era una decisión personal, pero también lo era política. Se trataba, como apunta Mangini, de una reacción a la represión masculina, una rebelión contra una vida de esposa y madre (25), pero también se trataba de una apuesta por la emancipación personal y, en esa medida, de un acto, poco habitual, a favor de la libertad femenina (26). Considero que esas decisiones se beneficiaron del carácter viril de Pasionaria y del peso específico que la militancia y el activismo, la lucha política en general, habían adquirido en su vida. Todo esto también contribuyó a que la creciente influencia entre las clases trabajadoras de los discursos de la maternidad y de la domesticidad femenina quedaran en un segundo plano. Dolores Ibárruri tuvo siempre presente su pasado y, quizás por ello, estimuló y apoyó la liberación de las mujeres del pueblo con las que compartía una historia común de sometimiento. Desde la Secretaría Femenina del Partido, Ibárruri insistió en la movilización de las mujeres y en su incorporación a la política (27). Mary Nash también ha destacado que fue de los pocos comunistas que planteó la cuestión femenina, llegando incluso a señalar que las mujeres no tenían que vivir en función de sus hijos y de su esposo (28).

En octubre de 1931 la revista Estampa publicó un reportaje sobre Dolores Ibárruri (29). A esas alturas Ibárruri era ya una figura de relevancia pública,

(24) IBÁRRURI (1972): 90.

(25) MANGINI (1997): 53.

(26) Robert Low afirma a propósito de esa ruptura que «La Pasionaria had been what we would now call a feminist», Low (1992): 102.

(27) CRUZ (1999): 125.

(28) NASH (1981): 177-78.

(29) «Una «terrible» bolchevique. La líder comunista Dolores Ibárruri. La Pasionaria». El reportaje y la entrevista está realizada por Víctor Ruiz de Añibarro, un periodista local, colaborador de Estampa y autor de obras de recopilación de leyendas y tradiciones vascas. En un momento de la entrevista Ibárruri resume los dos grandes hitos de su vida, el abandono del catolicismo y el descubrimiento del socialismo: «Yo era [...] una muchacha más entre las muchachas corrientes de estos pueblos. Iba a misa como todas ellas. Traté de hacerme maestra, pero no fue posible cursar los estudios pertinentes. Desde luego, nunca había pensado en esas cosas del Socialismo. [...] Cuando me casé [...] me encontré que (el marido) me hablaba del Socialismo y obrerismo con tanta insistencia que convertía nuestras conversaciones en monólogos. No era cosa de abandonarle a ese monólogo. Me trajo libros y leí». El artículo se reproduce completamente en García Castillejo (1995): 12 y 13. 
había escrito numerosos artículos en la prensa y se había presentado como candidata comunista por Bilbao a las elecciones legislativas. La crónica se proponía captar el verdadero universo de Pasionaria, «sorprenderla en su personalidad auténtica». Sin embargo, el mundo que refleja la crónica representa ya el pasado de Dolores Ibárruri. Arreglada con un vestido sencillo, un delantal y su pelo recogido en un moño bajo, Pasionaria es retratada en diferentes actitudes y posturas que tratan de capturar «su vida íntima de mujer de un minero humilde»: aparece puliendo una guadaña; en el lavadero lavando ropa con otras mujeres del pueblo; rodeada de los niños del barrio, en una evocación a lo que fue su aspiración juvenil de ser maestra; con sus hijos Rubén y Amaia, lo único que rescatará de ese universo que está a punto de dejar atrás; sentada en una silla y en la ventana de su casa obrera, con un libro entre las manos, a modo de homenaje a la herramienta que le permitió su desarrollo autodidacta y su promoción política y social (30). Solamente en un pequeño retrato de perfil vemos a la Pasionaria del futuro: Ibárruri de pie, vestida de negro y con la mano extendida pronunciando un discurso frente a un auditorio fundamentalmente masculino. En ese momento, Dolores tenía treinta y seis años, sin embargo el periodista señala: «Apenas tiene más de cuarenta años y numerosos hilos de plata cabrillean en el negro de su cabellera. La vida de esta mujer no ha debido de ser fácil ni blanda». Ciertamente, no había sido una tarea fácil convertirse en una dirigente política en un partido de hombres. Tampoco lo había sido la decisión de emanciparse y trasladarse con sus hijos a una ciudad grande y desconocida como Madrid. Para lograrlo, Dolores Ibárruri había sabido aprovechar rasgos de la feminidad no convencionales, que ofrecían a las mujeres ciertos márgenes de legitimidad sin contradecir su definición sexual ni su respetabilidad.

Pero lo que estaba por venir durante los años treinta también iba a estar sembrado de dificultades: convertirse en el miembro de más edad del comité ejecutivo de un partido de hombres y llegar a ser una autoridad incontestable dentro del mismo y de la Internacional Comunista (31); transformarse en una figura pública y reconocida del nuevo panorama político abierto tras la proclamación de la II República y, especialmente tras la victoria electoral del Frente Popular, convertirse en una líder natural del mismo; finalmente, llegar a ser un símbolo nacional de la España republicana, una vez comenzada la Guerra Civil en 1936.

La respetabilidad y el reconocimiento que alcanzó Pasionaria estuvieron relacionados con la ambigüedad identitaria que le proporcionó la figura de la mujer del pueblo. Así, bajo esa cobertura, Dolores Ibárruri pudo mostrar actitu-

(30) Santiago Carrillo destaca en su memoria sobre Ibárruri que empezó destacando «por su capacidad de escribir», CARRILlo (2008): 61.

(31) Como reconoce el mismo Santiago Carrillo: «Se trata de un acontecimiento extraordinario, casi único en la España de entonces», ibidem: 62. Dolores Ibárruri fue la única mujer dirigente de la Internacional desde su elección en 1935, con motivo del VII Congreso de la IC, FALCÓN (1996): 231. 
des disidentes de la feminidad normativa y tomar decisiones radicales que contribuyeron a su emancipación personal. Como veremos a continuación, priorizar su militancia y la dedicación a la lucha política por encima de todo, tanto como cultivar una imagen pública austera y alejada del peligro de sexualización fueron elementos que contribuyeron a hacer de Pasionaria una figura pública poderosa, pero también alejada de los convencionalismos de una feminidad atravesada por el binarismo sexual.

\section{LA EXPLOSIÓN PÚBLICA DE PASIONARIA}

En el año 1931, tras la proclamación de la II República, la actividad del PCE se centró en la denuncia de lo que consideraba todavía un régimen burgués. La militancia comunista pagó su radicalidad con detenciones, represión y clandestinidad. Su órgano de prensa, Mundo Obrero, fue habitualmente confiscado. Dolores Ibárruri fue detenida por primera vez a los pocos días de su llegada a Madrid, acusada de ocultar en su casa de Vizcaya a compañeros perseguidos por la policía. Fue precisamente en 1932, durante esa prolongada detención, el momento en el que Pasionaria protagonizó uno de los episodios más decisivos de su nueva trayectoria dentro del partido, que garantizaría su permanencia dentro del buró político y que le ofreció la oportunidad de realizar una declaración de fe hacia la Unión Soviética. Además, este acto también significó reafirmar su ruptura con el pasado, esta vez con sus camaradas vizcaínos encabezados por José Bullejos, con los que había construido el Partido Comunista hasta ese momento. En 1932, tras la elección de una dirección general encabezada por Bullejos y en la que se encontraba también Dolores Ibárruri, se desató una lucha interna en la que un grupo opositor, apoyado por la Internacional Comunista, terminó por expulsar a toda la dirección, nombrando un nuevo buró político bajo la secretaría general de José Díaz (32). El nuevo comité pidió a Dolores Ibárruri una exposición pública de sus posiciones políticas. Se trataba de una exigencia de autocrítica oficial que Pasionaria realizó por medio de una carta publicada en Mundo Obrero el 5 de diciembre de 1932.

«Yo, vieja comunista, no quiero ni puedo rehuir, [...], el hacer una autocrítica severa de pasadas actuaciones, $[\ldots]$, no personalmente, sino en interés del Partido,

(32) Rafael Cruz analiza este trascendental acontecimiento minuciosamente en CRUZ (1999): 83-90. La orientación de José Bullejos trataba de romper las limitaciones que el radicalismo izquierdista imponía al incremento de la implantación del partido entre las masas obreras. La nueva dirección, auspiciada por la Internacional Comunista y por Vittorio Codovilla, trataba de mantener una posición más ultraizquierdista y probablemente sectaria. En todo caso, también se estaba resolviendo el control del poder en el partido: la dirección de Bullejos no era proclive a tolerar las injerencias, y la Internacional Comunista, por su parte, no toleraba la autonomía de ninguna sección. Para un estudio extenso de la relación de la III Internacional y el PCE ver ELORZA Y BIZCARRONDO (1999). 
recabando para mí el tanto de culpa que me haya podido corresponder. Unida al grupo de renegados, no como tal, sino por ostentar este la dirección del Partido, por una convivencia de muchos años de lucha que crearon entre nosotros lazos de sincero afecto, para mí ha resultado muy doloroso tener que abandonar a estos camaradas en una revuelta del camino; si dijese otra cosa no sería sincera.

Pero cuando de luchar por el engrandecimiento del Partido se trata [...], para mí no existen amistades, afectos y familia ni amigos; no existe más que el Partido y la revolución y en aras de esto sacrifico todo lo demás» (33).

Rafael Cruz destaca que en el término «vieja comunista» Ibárruri trata de rescatar, frente a la juventud de la nueva dirección, la autoridad que la edad, la experiencia y los sacrificios realizados otorgan (34). Era necesario hacerlo así porque, en el hecho de abjurar de su anterior trayectoria y de sus compañeros, era preciso rescatarse a sí misma como un valor para la nueva dirección. Pero eso no era suficiente, había que romper con sus camaradas y alinearse con la nueva dirección, lo que, de forma implícita, significaba aceptar abiertamente la excesiva injerencia de la Internacional Comunista en la política interna del PC. Para lo primero, no hay piedad en el abandono de sus camaradas. Como ya he señalado, en alguna medida aquellos formaban parte de un pasado que, en lo personal, ya le había costado una ruptura trascendental en su vida. Respecto al Partido y a la Internacional Comunista, esa declaración era un compromiso absoluto hacia el Partido pero, sobre todo, se trataba de una manifestación pública de fidelidad hacia la Internacional Comunista que, a los ojos de Ibárruri, parecía ser la única y auténtica representación de la Unión Soviética y también de la revolución obrera. Esa declaración, que le permitió saltar de una dirección a otra, fue la demostración de que había aprendido y aceptado la importancia de no contravenir los dictados de la dirección internacional, algo que en el siguiente periodo de su vida se revelaría como un aprendizaje fundamental.

Pero lo que resulta más trascendental para nuestro análisis de esa declaración, es el hecho de que Ibárruri puso por delante de las relaciones personales y de la familia su dedicación al Partido. En buena medida, la lucha interna por la dirección del partido le exigió una vez más tomar una decisión poco convencional, alejada de lo que socialmente se esperaba de una mujer y de una madre. Ciertamente, tras su confesión, se produjo una intensificación de su entrega a la causa, lo que no era sino un anuncio de las crecientes contradicciones que el incremento de su vida militante acarrearía a su vida familiar y doméstica. Cuando en enero de 1933 Dolores Ibárruri salió de la cárcel de Larrínaga, volvió a Madrid con sus dos hijos pero, llegado a este punto, las dificultades para compaginar su creciente activismo y la atención familiar se harían insalvables. En

(33) IBÁRRURI (1932): 1.

(34) CRUZ (1999): 87. 
la primavera de 1935, Ibárruri aceptó la sugerencia del Partido de enviar a sus hijos a la URSS, poniendo fin, así, a una situación precaria (35).

A partir de su integración en el nuevo buró político a finales de 1932 y hasta el comienzo de la Guerra Civil, su trayectoria fue adquiriendo mayor prestigio y una dimensión internacional (36). Al año de la crisis del buró político, Dolores Ibárruri fue elegida delegada del Partido al XIII Pleno de la IC. En esa circunstancia, sobre ella recayó la responsabilidad de realizar el saludo del PCE en el XVII Congreso del Partido Bolchevique. Ese encargo le dio la oportunidad de afirmar una trayectoria como oradora que sería su actividad más sobresaliente durante los años de la II República y la Guerra Civil. Dolores, en carta manuscrita al buró del PCE, describía su intervención de la siguiente manera:

Compañeros, podéis estar orgullosos; la mujer del pobre minero de Somorrostro, pero representante del PCE de un país donde el movimiento ascendente de la revolución plantea de manera urgente la lucha por la conquista del poder, hizo poner en pie, en ovaciones clamorosas a todo el Congreso, todas las intervenciones giraban después en torno a la intervención de la delegada española. Stalin se interesó enormemente por conocer mi origen, situación, etc. (37).

La capacidad de seducción de la oratoria de Ibárruri se vio confirmada en ese acontecimiento y ese dato terminó resultando una constante de la labor de Ibárruri en el Partido como portavoz de los ideales comunistas. Todo ello contribuyó a hacer de ella una pieza imprescindible en la trayectoria ascendente del Partido Comunista, especialmente a partir de 1934 y hasta el final de la Guerra Civil. En esa coyuntura, su conversión en un personaje público y en una líder de masas se debió, en buena medida, a la capacidad de sus discursos para emocionar a la audiencia de diferentes auditorios y, posteriormente, a las masas en los mítines y en las movilizaciones obreras y populares. Su talento en el dominio de la retórica, del espacio escénico y de la utilización de su propia figura han sido sobradamente reconocidos. Como ya hemos señalado anteriormente, la imagen de sí misma que Ibárruri cultivó fue la de mujer del pueblo, vestida de negro, el pelo recogido en moño y unos pendientes de azabache como única joya. Así, a pesar de que sus decisiones vitales la habían convertido en una mujer emancipada, Ibárruri renunció a construirse una imagen a la moda, de mujer moderna e independiente (38). Teresa Pamiés afirma que Ibárruri era consciente de que «gran parte de su fuerza

(35) CRUZ (1999): 90. Dolores reconoce en su autobiografía: «Era un nuevo sacrificio que debía imponerme, y lo acepté, con la seguridad de que lo que de momento era penoso para ellos y para mí, se compensaba porque para ellos terminaba el azar de una vida irregular, y para mí representaba un alivio en la angustia de cada día por su situación», IBÁRRURI (1972): 250.

(36) En 1933 viajó a la URSS como delegada del PCE en el XIII Pleno de la IC y en 1934 encabezó la delegación española al Congreso Mundial contra la Guerra y el Fascismo que tuvo lugar en París en 1934. VÁZqueZ MonTALbán (1995): 65.

(37) IBÁRRURI (1934).

(38) En ese sentido, algunos autores sostienen que Ibárruri no desafió los standards patriarcales sobre lo que tenía que ser una mujer, DELLINGER (2014): 308. 
estaba en su presencia, en la confianza que inspiraba su aspecto de mujer de pueblo, confianza que podía perder con una pequeña extravagancia» (39). Ciertamente, George L. Mosse ha destacado que en aquellos momentos existía la convicción de que la unión de características externas e internas proyectadas por un determinado estereotipo afectaba a la personalidad en su conjunto y que «las formas del cuerpo y la cara facilitaban la «lectura» del supuesto valor del individuo», siempre que existiera un standard de belleza al que pudiera asociarse el estereotipo (40). Si nos centramos en la cultura comunista de los años treinta, el prototipo de mujer moderna había quedado identificado, tanto con un modelo de mujer fatal que parecía que buscaba corromper a los hombres, como con un tipo de mujeres que había sucumbido a las tentaciones del consumo y de la sociedad de masas (41). En alguna medida, en la cultura comunista, lo que predominaba como imagen femenina era el estilo soviético de heroína conductora de tractor combinada con la estoica madre amorosa representada por Käthe Kollwitz (42). La literatura alemana comunista también transmitía que el prototipo de mujeres que luchaba por una participación más igualitaria en la lucha de clases no se correspondía con el de la mujer moderna, sino más bien con el de una imagen femenina tradicional, cercana, incluso, a la Virgen María (43). Considero que el maniqueísmo entre ese estereotipo de mujer moderna sexualizado y la imagen de mujer del pueblo, digna en su austeridad, formó parte de la subjetividad de Ibárruri hasta el final de sus días. En 1977, a propósito de ello, exclamaba: «Hijo, el negro es lógico para una persona de clase modesta como yo. Yendo de negro puedes ir decentemente a todas partes. ¿Cómo voy a salir yo a la calle vestida de rojo como una bandera?» (44). La apariencia de mujer del pueblo, el negro de sus vestidos y su severidad transmitían la idea del luto, del sufrimiento y de la madre sacrificada. Pero, a la vez, la austeridad de esa indumentaria le permitió mostrar seriedad y, en cierta medida, esto resultó una credencial frente al peligro de sexualización que conllevaba el hecho de ser mujer. Ciertamente, la imagen de mujer del pueblo constituía una imagen femenina tradicional pero, por ello mismo, resultaba incuestionablemente respetable a los ojos de sectores importantes de la población española. Todo ello permitió a Dolores Ibárruri mantener una ambigüedad pública. No podemos olvidar que el negro era también el color masculino por excelencia, lo que le daba la posibilidad de transmitir, tanto una imagen de mater dolorosa, como de mujer viril.

(39) PAMIÉs (1977): 89. Robert Low sostiene que Ibárruri «remained a conservative figure in her personal habits and tastes throught her life, for example abhoring women who smoked, drank or wore trousers», Low (1992): 11.

(40) Mosse (2001): 31.

(41) Gruber y Graves (1998): 146

(42) Ibidem: 146.

(43) Referencia de Mosse a la novela El Ruhr en llamas de Karl Grunberg publicada en 1929, Mosse (2001): 152.

(44) Cita recogida de una conversación entre Ibárruri y Carabantes y Cimorra en 1977, VÁZqueZ MonTALBÁN (1995): 68. 
En todo caso, la imagen que Ibárruri se construyó como oradora y figura pública estuvo condicionada por emociones muy tempranas, que se remontaban a los momentos en que de niña asistía a los mítines que se organizaban en la cuenca minera de Vizcaya. Como ella misma confiesa:

No me perdía uno. Y me bebía materialmente lo que decían los oradores, fuesen socialistas o carlistas, aunque no comprendiese totalmente el objetivo político del acto. Pero la música del idioma, la palabra sonora, la crítica aguda, el apóstrofe violento, la frase sarcástica o la hiriente ironía, me entusiasmaban y después contaba en casa lo que había oído y me había producido mayor impresión. Los nombres de los socialistas Facundo Perezagua e Indalecio Prieto, de la republicana Belén Sárraga, y en el polo opuesto, de los carlistas Víctor Pradera y Vázquez Mella, van unidos a mis primeras inconscientes emociones políticas infantiles (45).

Ibárruri había aprendido a valorar los componentes de un discurso y, en su madurez, logró, a través de su cuerpo y de su presencia, la capacidad de seducción y de transmisión de emociones por medio de la alocución oral que tanto había admirado en otros oradores/as (46). Sin embargo, como ya hemos señalado, su aspecto y su apariencia jugaron un papel importante también en esa puesta en escena. El corresponsal Ilya Ehrenburg supo reflejar la ambivalencia de la figura de Dolores Ibárruri: «Un rostro hondamente espiritual, una mirada exigente y severa, a la vez que llena de consideración [...]» (47). La sobriedad de su porte y la severidad del negro contribuían a transmitir un conjunto de sentimientos polivalente: la valentía, atributo viril por excelencia; la generosidad y la entrega, convencionalmente atribuidos a la naturaleza maternal. La polisemia de su ambigüedad constituyó una de las claves de su éxito.

A partir de 1934, su prestigio como figura pública y como activista fue cimentándose como consecuencia de acciones personales que, como plantea Rafael Cruz, demostraron su capacidad de arrojo y empuje y que, paradójicamente, «otros miembros de su partido y de otros grupos afines no imaginaban posibles o no contemplaban como convenientes o necesarias» (48). El Partido Comunista había destinado a Dolores Ibárruri a la creación de la Secretaría de

(45) IBÁRRURI (1972): 136-137.

(46) María Dolores Ramos sostiene que virtudes personales de la identidad republicana como el ánimo, la energía, el arrojo y la audacia eran cualidades consideradas viriles de las que las librepensadoras andaban sobradas. Esta historiadora recoge una anécdota especialmente elocuente a propósito del carácter viril de Belén Sárraga: «El cronista republicano Emilio López Domínguez comentó, tras escucharla en un mitin en Córdoba: "Y... ¿lo digo? Esa mujer ha demostrado que aquí no hay hombres"», RAMOS (2005): (66).

(47) Citado en CRUZ (1999): 133.

(48) Ibidem: 96. Cruz sostiene que Ibárruri se especializó en tareas de organización y movilización y que no se inmiscuyó en la toma de decisiones de la dirección, de tal manera que nunca se entrometió en la estrategia impulsada por la IC, Ibidem: 94. El tipo de acciones que emprendió Ibárruri son recogidas también por Cruz: viaje a Asturias tras la revuelta del 34 para trasladar a los niños a Madrid; las gestiones para liberar a los presos de las cárceles tras la victoria del Frente Popular; descenso a la mina Cadavio en Asturias en solidaridad con los obreros 
la Mujer. Esa tarea, aparentemente marginal, le permitió mantener cierta autonomía respecto a otros dirigentes del Partido y, a la vez, aumentar su prestigio organizando los Comités de Mujeres contra la Guerra y el Fascismo, un organismo de gran trascendencia internacional, y en la que el Partido Comunista jugó un papel director, gracias, entre otras cosas, a la implicación de Dolores Ibárruri como presidenta (49).

En 1936, una vez que Dolores Ibárruri fue elegida diputada tras las elecciones del Frente Popular, se produjo una contienda en la cámara de diputados que puso de manifiesto el carácter viril de Pasionaria. Su intervención, que era una de las primeras que realizaba en el parlamento, se produjo el 16 de junio de 1936 y respondió a una interpelación al gobierno «sobre el estado de subversión en que vive España», realizada por algunos diputados de la derecha, encabezados por Gil Robles y Calvo Sotelo. Las palabras de Ibárruri fueron las siguientes:

[...] Para evitar las perturbaciones, para terminar con el estado de desasosiego que existe en España, no solamente hay que hacer responsable de lo que pueda ocurrir a un Sr. Calvo Sotelo cualquiera, sino que hay que comenzar por encarcelar a los patronos que se niegan a aceptar los laudos del Gobierno. Hay que comenzar por encarcelar a los terratenientes que hambrean a los campesinos; hay que encarcelar a los que con cinismo sin igual, llenos de sangre de la represión de Octubre, vienen aquí a exigir responsabilidades por lo que no se ha hecho. Y cuando se comience por hacer esa obra de justicia, Sr. Casares Quiroga, señores Ministros, no habrá Gobierno que cuente con un apoyo más firme, más fuerte que el vuestro, porque las masas populares de España se levantarán, repito, como en el 16 de Febrero, y aun quizá, para ir más allá, contra todas esas fuerzas que, por decoro, nosotros no debiéramos tolerar que se sentasen aquí (50).

Como plantea Rafael Cruz, la intervención de Ibárruri gustó a los partidos colaboradores del gobierno y al gobierno mismo, no tanto por la denuncia de la represión de Asturias o por la petición de procesamiento para Gil Robles o Calvo Sotelo, sino por lanzar una crítica feroz contra los grupos que pretendían crear fisuras dentro de la mayoría parlamentaria.

Gracias a su discurso, Dolores Ibárruri logró convertirse en una de las cabezas visibles del Frente Popular y en una líder natural del mismo. Ese

encerrados; ayuda a una mujer parturienta expulsada de una maternidad madrileña y un largo etcétera. Ibidem: 96.

(49) Aunque en sus filas abundaron socialistas y republicanas el control estuvo siempre en manos de los comunistas, en CENARRo (2006): 170. Mercedes Yusta sostiene que así como el Comité Nacional Antifascista organizado por el PCE, y en el que también participaba Ibárruri junto con Irene y César Falcón, Francisco Galán y Wenceslao Roces, no alcanzó la popularidad esperada entre las masas, la organización de mujeres antifascistas «sí logró tomar proporciones de movimiento de masas y logró hacer del antifascismo una consigna unitaria más allá de las filas del partido, aunque este mantuviese subrepticiamente el control sobre el movimiento femenino», en YUSTA (2009): 75.

(50) El texto del Diario de Sesiones del Congreso de Diputados en García Castillejo (1995): 177. 
protagonismo adquirido no haría sino incrementarse durante la Guerra Civil. Así, a propósito de lo ocurrido aquel día en la Cámara de Diputados, el propio Gil Robles puso de relieve en sus memorias que: «Después de seis horas de discusión [...] solo Dolores Ibárruri logró dar coherencia al Frente Popular con un brioso discurso». De la misma manera, el bloque progresista no ocultó su entusiasmo: El Socialista declaraba: «Magnífica revelación parlamentaria [...] una nueva voz y auténticamente proletaria»; El Liberal ponía de relieve que era una mujer la que había avergonzado a las derechas; La Libertad destacaba: «Figura severa, dramática, de inconfundibles perfiles de heroína»; El Sol opinó que el discurso de Pasionaria había sido de «gran fuerza y en ocasiones emoción». Pero quizás lo que más puso de relieve el carácter viril del acontecimiento protagonizado por Dolores Ibárruri fueron las declaraciones del político de Unión Republicana, Francisco Gómez Hidalgo que señaló: «Pasionaria ha hablado hoy como un hombre. Como el único hombre que ha hablado esta tarde en la Cámara» (51). Creo que es posible interpretar ese acontecimiento como la culminación de un proceso de construcción de una figura femenina no convencional, que había logrado escapar de los límites marcados por una visión rígidamente binaria y biologicista del orden de género y que se encontraba en las antípodas de la imagen maternal que terminaría siendo su mítica seña de identidad pública.

Como hemos tenido la oportunidad de comprobar, a través de una trayectoria personal compleja y de un proceso de emancipación singular, Pasionaria había logrado connotar su cuerpo de mujer con los valores excelsos, pero típicamente masculinos, de un líder político. Sin embargo, esto no tardaría en cambiar. La figura de Pasionaria, en las circunstancias excepcionales que se abrieron en el contexto de la Guerra Civil, terminaría resignificándose para llegar a encarnar públicamente a la gran madre republicana, una imagen femenina poderosa, pero menos transgresora y ambigua que la Pasionaria viril que, en un momento dado, se había mostrado capaz de llevar los pantalones del Frente Popular. Todo ello fue el resultado de un proceso rápido en el que la nacionalización de la guerra, y el estricto orden sexual y de género que se impuso en paralelo, jugaron un papel decisivo.

\section{La Guerra Civil y la CONVERsión De PaSiONARIA EN UN SÍMBOLO NACIONAL ESPAÑOL}

En el verano de 1936, una vez dio comienzo la Guerra Civil, la organización de milicias fue la forma en la que se encauzó la voluntad popular de hacer frente

(51) La valoración del debate parlamentario y las consecuencias del mismo en la prensa, incluidas las memorias de Gil Robles, en Cruz (1999): 106 y 107; también en VÁZQuez MonTALBÁN (1995): 80. 
a los sublevados. Dolores Ibárruri, haciendo honor a su identidad como mujer del pueblo, exhortó a las mujeres a pelear junto a los hombres y a crear unidades de milicianas dentro del V Regimiento: « ¡Jóvenes, en pie para la pelea! ¡Mujeres heroicas, mujeres del pueblo, acordaos del heroísmo de las mujeres asturianas; luchad también vosotras al lado de los hombres para defender el pan y la tranquilidad de nuestros hijos amenazados» (52).

En el pensamiento de Dolores Ibárruri, la identificación de la defensa de la revolución obrera con la emancipación de las mujeres era un estímulo para animarlas a participar en la lucha por la defensa de la República (53). Ibárruri quería transmitirles la importancia de «reclamar un puesto en la lucha, porque no queremos recibir la victoria como un regalo de los hombres de España, sino como algo que nosotras conquistemos» (54). Sin embargo, como Mary Nash ha puesto de relieve, el enaltecimiento de la figura heroica de la miliciana como símbolo de la movilización popular fue breve. Para octubre del 36 se reguló su retirada de los frentes y su imagen, o bien quedó desprestigiada bajo el argumento de destruir supuestamente el desarrollo del esfuerzo bélico, o bien utilizada para incitar a los hombres a asumir sus deberes patrióticos. En su lugar, se reforzó la imagen de «la madre combatiente», dedicada a la causa de la guerra desde la retaguardia (55).

Ciertamente, la Guerra Civil enseguida adoptó un formato de guerra patriótica también en el bando republicano y, en esa medida, la identificación entre la defensa de la nación y la exaltación de la figura de la madre resultaron definitivos para el cambio de orientación que adquirieron los discursos de Pasionaria. Por otro lado, el significado de su propia figura como líder comunista femenina fue acercándose cada vez más a la imagen de la madre protectora y sufridora. Núñez Seixas ha destacado que el bando republicano tomó conciencia de que invocar a la patria era más efectivo, a la hora de movilizar a la sociedad, que apelar a la revolución, al internacionalismo proletario o a la legalidad republicana (56). Desde el punto de vista de este autor, la fusión del pueblo y de la nación se produjo a través de imágenes femeninas heroicas como la de Agustina de Aragón, que fue

(52) IBÁRRURI (1936): 4. Robert Low refiere que Ibárruri instó a Enrique Castro, comandante en jefe del V Regimiento, a crear unidades de milicianas dentro del mismo. Low (1992): 103.

(53) Mercedes Yusta sostiene que ya en los mítines de la campaña del Frente Popular en febrero de 1936, Dolores Ibárruri había creado un tipo de discurso dirigido a las mujeres que apelaba al argumento de la emancipación, pero también al de la maternidad, YUSTA (2011): 268.

(54) Discurso de Pasionaria en los primeros días de agosto ante las tres compañías de milicianas, según Irene Falcón, organizadas por sugerencia suya, en FALCón (1996): 151.

(55) NASH (2008): 77. Geraldine Scanlon también pone de relieve, a propósito de Lina Odena, militante comunista que se suicidó antes de caer en manos de los falangistas en septiembre del 36 en Almería que, aunque se formó un batallón con su nombre como ejemplo a seguir, más que sus proezas militares, las mujeres debían tratar de imitar su «desinteresada dedicación al esfuerzo bélico», SCANLON (1986): 294.

(56) NÚÑEZ SEIXAS (2006): 30. 
incorporada «como arquetipo de la presencia femenina del pueblo y por tanto de la "madre" España combatiente» (57). Como George Mosse ha puesto de relieve, el nacionalismo representa la respetabilidad por medio de un estricto orden de género en el que, por un lado, las figuras femeninas representan a la patria a través de la madre virtuosa y, por otro, el «carácter nacional» se afirma por medio de una «masculinidad viril», presta a defender la nación (58). Así, en el bando republicano, la transformación de la Guerra Civil en una guerra nacional favoreció la culminación de un proceso de enaltecimiento de los discursos de la maternidad y de la domesticidad femenina que se habían prodigado durante los años veinte y treinta (59). Todo ello tuvo su consecuencia directa en la neutralización de las milicianas y de su papel activo en el frente y, en general, fue definitorio de las funciones que las mujeres debían tener en la guerra. Como diferentes autoras han destacado, se reforzó la idea de que su labor, como madres, esposas e hijas, estaba en la retaguardia; se apeló a sus sentimientos como madres o compañeras sufrientes para reafirmar su entrega al trabajo de apoyo en la vida civil y al consuelo del soldado; se utilizó la identificación entre la patria invadida y la mujer indefensa para espolear el coraje de los combatientes (60).

Todo esto tuvo una influencia fundamental en la orientación de los discursos transmitidos públicamente por Dolores Ibárruri y en la forma en que su propia figura fue resignificada en el contexto de una guerra en el que el bando republicano fue acusando crecientes problemas de cohesión interna y en el que había que hacer frente a graves dificultades para ganar la guerra. Célebres manifestaciones públicas de Pasionaria desde el otoño de 1936 son una muestra de ese giro conservador del significado del orden de género que se produjo durante la Guerra Civil:

Lucháis por librar a vuestras mujeres, a vuestras madres, a vuestras hermanas y a vuestras novias de las atrocidades de los fascistas. [...] Milicianos de Madrid: una vez más os repito la necesidad de mantener cada día con más fuerza el sentimiento de victoria[...]. Si ellos triunfaran en el campo de concentración pensaríais que vuestras mujeres y vuestras madres os dirían: "Llorad como mujeres, ya que no supisteis luchar como hombres" (una gran ovación acoge las últimas palabras de Pasionaria) (61).

(57) Ibidem: 87.

(58) Mosse (2001): 129

(59) Mónica Moreno sostiene que en los discursos de Pasionaria el registro victimista y maternalista coexiste con el registro feminista y pone como ejemplo tanto el discurso realizado por Dolores Ibárruri con ocasión del 8 de marzo de 1938 como el pronunciado en la Conferencia Provincial del Partido ese mismo año. Para esta autora los discursos de Ibárruri mantienen un difícil equilibrio entre la defensa de la igualdad y la complementariedad de los sexos, en MORENO (2015): 138.

(60) NASH (1981): 245; NASH (1999): 156; Cenarro (2006): 176; SCANLON (1986): 314; Hamilton (2001): 19; para el caso vasco ver Llona (2014): 195-200. Tiene especial interés la utilización por parte de Brigitte Studer del término «desvirilización» de las funciones femeninas para referirse a la evolución de las representaciones de mujeres a lo largo de la Guerra Civil en el campo republicano, citado por YUSTA (2009): 82.

(61) IBÁRRURI (1936): 4. Es posible ver esa evolución del sentido patriótico de la guerra expresado en términos de género en diferentes alocuciones de Pasionaria: desde el «¡No pasarán!» 
Los rígidos códigos de la diferencia sexual se habían impuesto y una dicotomía de género que representaba a las mujeres como sujetos pasivos y a los hombres verdaderos, solamente como soldados victoriosos, sustituyó a las proclamas anteriores de Pasionaria que instaban a las mujeres del pueblo a luchar. Se había reinstaurado un imaginario sexual de orden que ya no se abandonará durante el transcurso de la guerra: «iMujeres de Madrid! [...]. Gritadles que nuestros hombres no se dejarán aplastar» (62).

Esa radicalización patriótica afectó también a la propia resignificación de la figura de Pasionaria. Así, de ser la personalidad más visible y provocadora del Partido Comunista, se convirtió en una líder de masas, una presencia singular y extraordinaria con reconocida capacidad tanto para conmover y movilizar a los soldados republicanos en los frentes, como para ayudar a las madres y esposas en la retaguardia a aceptar con abnegación la muerte de sus hombres (63). En ese momento, emergió con toda su fuerza la imagen de Pasionaria como gran madre. Gina Herrmann plantea que se produjo una fusión de la «madre patria» y de la «madre Pasionaria» que, desde su punto de vista, resultó ser una de las armas más efectivas de la propaganda republicana en la Guerra Civil (64).

Autoras como Pamela Radcliff y Nerea Aresti han destacado la falta de una identidad nacional homogénea en el bando republicano. La división entre diferentes visiones de España, la República democrática y la República de los trabajadores (65), se tradujo durante la guerra en una tensión entre diferentes interpretaciones de lo que significaba la guerra: para unos, una expresión sangrienta de la lucha de clases, mientras que para otros, una contienda para salvar España, es decir, una guerra interpretada en términos nacionales (66). La emergencia de Pasionaria como madre heroica y como una afirmación de españolidad constituyó un nuevo símbolo patriótico, que contribuyó a dar identidad nacional a la causa republicana, siempre bajo la cobertura de argumentaciones

del 18 de julio de 1936 lanzado en los micrófonos de Unión Radio en el Ministerio de la Gobernación, a «El pueblo español prefiere morir de pie que vivir de rodillas» de septiembre de 1936 en el Velódromo de Invierno de París, al «Más vale ser viuda de héroes que mujeres de cobardes» de octubre de 1936 en un mitin en Madrid, las tres referencias de las alocuciones recogidas por CRUZ (1999): 99.

(62) IBÁRRURI (1938): 13.

(63) Mangini (1997): 56.

(64) Herrmann (1998): 196. A la vez, Yannick Ripa sostiene que fue precisamente esa imagen de madre dolorosa de la retaguardia la que ha reclamado toda la atención, favoreciendo que el mito Pasionaria pueda ser utilizado para reforzar las relaciones tradicionales entre los sexos, en Ripa (1997): 6. Yusta plantea que en 1945 cuando se realizó el primer congreso de la UFF (Union des Femmes Françaises), donde Dolores Ibárruri tomó la palabra para reclamar el apoyo de las mujeres francesas para acabar con Franco, también lo hizo apelando a la maternidad como argumento de movilización y de autoridad, algo que, en su opinión, terminaría imponiéndose en la organización de mujeres exiliadas españolas y también en la FDIM (Federación Democrática Internacional de Mujeres), en YUSTA (2009): 90.

(65) RADCLYFF (1997): 325.

(66) ARESTI (2012): 69. 
e imaginarios que destacaban la guerra como una guerra de independencia y de liberación social (67). Marie Marmo Mullaney ha destacado que fue el PCE, ante las críticas de sus rivales políticos por su plegamiento a Moscú, el que más obstinadamente representó la guerra como una lucha de liberación nacional, haciendo referencia a las gloriosas tradiciones españolas y presentando en ese contexto a Ibárruri como un símbolo de pura españolidad (68):

Olvidaban que España tuvo una guerra de independencia -proclamaba Ibárruri- y que nuestro pueblo escribió en ella las páginas heroicas y gloriosas de Gerona, de Zaragoza, de Bailén, y de Madrid; que, más recientemente, supo aportar también a la historia revolucionaria del proletariado las páginas de oro del glorioso Octubre asturiano... Desconocían a nuestro pueblo (69).

Que Pasionaria llegara a convertirse, como ella misma declaró, «en una madre camarada de todos mis compañeros antifascistas» (70), constituyó un fenómeno que permitió, gracias al poder estabilizador del orden de género, restañar en alguna medida las fisuras abiertas dentro del bando republicano: la feminización de Pasionaria venía a consolidar el papel heroico de los hombres republicanos en la defensa de la nación, reafirmando su hombría como combatientes. Por otro lado, la resignificación de Pasionaria como madre también constituyó una forma de ganar legitimidad en la confrontación por encarnar la imagen ideal de la identidad nacional española en el contexto de una guerra que, precisamente, enfrentaba dos formas opuestas de representar e imaginar la españolidad (71). La representación de Pasionaria como una madre heroica y sufriente, encarnación de la virtud y convertida, de alguna manera, en mito y talismán de la identidad española, contribuía a consolidar a la República como la más auténtica de las expresiones nacionales españolas. De alguna manera, ambos bandos entendieron la importancia del símbolo representado por Pasionaria y, así, si para la memoria de la Guerra Civil en el bando republicano Dolores Ibárruri ha pasado a ser la Gran Madre, para el bando sublevado Pasionaria se convertiría en la «tiorra roja», máxima reencarnación del desorden social y de la barbarie (72).

Como hemos tenido la oportunidad de comprobar a través de la trayectoria de Dolores Ibárruri, los significados de la feminidad durante los años veinte y

(67) NÚÑEZ SEIXAS (2006): 41. Este autor da referencia de los discursos pronunciados por Pasionaria en ese sentido el 19 y el 20 de julio 1937, el 8 de marzo de 1938 en Mundo obrero y el 1 de abril de 1938 en Trabajadoras.

(68) Citado por Hamilton (2001): 18.

(69) Pasionaria 12 de agosto de 1937, citado en NúÑEZ SEIXAS (2006): 29.

(70) MAestro y CARRILLO (2004): 217.

(71) ARESTI (2014b): 147.

(72) VÁZQuEZ MonTAlBÁN (1995): 168. Susanna Tavera confirma que el bando franquista, de forma reiterada, aludía a la «masculinidad», entendida como anulación del modelo de género basado en el recato y la sumisión, al referirse no solo a la Pasionaria, sino a las mujeres republicanas en general, en TAVERA (2005): 220. 
treinta fueron cambiantes e inestables. Así, figuras como la mujer del pueblo y elementos heroicos de carácter masculino pertenecientes a la tradición cultural de la clase obrera pudieron ser reinterpretados y utilizados para construir subjetividades femeninas híbridas, alejadas del estereotipo de la diferencia sexual que, por otra parte, constituyó un ideal de género que no dejó de incrementar su legitimidad durante aquellos años. Sin embargo, la existencia de unas formas de subjetividad femenina ambiguas permitió que una mujer como Pasionaria consiguiera impulsar su propia emancipación como mujer y proyectarse públicamente, de forma poderosa e influyente, como líder político, logrando conjurar dos peligros: por un lado, la sexualización/desvalorización femenina y, por otro, el cuestionamiento de su propia respetabilidad como mujer. A la vez, este pequeño ejercicio que hemos realizado de deconstrucción de la subjetividad de Ibárruri ha permitido trascender su estereotipada y común identificación con la figura de la madre, un significado este que durante la Guerra Civil saturó la imagen de Pasionaria y que, a posteriori, terminaría imponiéndose como el único y más 'auténtico' núcleo de su identidad.

\section{BIBLIOGRAFÍA}

Arbaiza, M. (2015). Cuerpo, emoción y política en los orígenes de la clase obrera en España (1884-1890). Ayer, 98 (2), 45-70.

Aresti, N. (2012). Masculinidad y nación en la España de los años 1920 y 1930. Melanges de la Casa de Velázquez, 42 (2), 55-72.

- (2014a). De heroínas viriles a madres de la patria. Las mujeres y el nacionalismo vasco (1893-1937). Historia y Política, 31, 281-308.

- (2014b). The Battle to Define Spanish Manhood. En A. G. Morcillo (ed.). Memory and Cultural History of the Spanish Civil War. Realms of Oblivion (pp. 147177). Leiden-Boston: Brill Publishers.

Blanco, A. (1986). In Their Chosen Place: On The Autopbiographies of Two Spanish Women of the Left. GENRE XIX, 431-445.

Camino, J. y Ibárruri, D. (2006). Pasionaria. Conversaciones en Moscú. Castellón: Ellago.

Carrillo, S. (2008). Dolores Ibárruri Pasionaria, una fuerza de la naturaleza. Barcelona: Planeta.

Cenarro, A. (2006). Movilización femenina y Guerra Civil. Historia y Política, 16, 16-43.

Cruz, R. (1999). Pasionaria, Dolores Ibárruri, historia y símbolo. Madrid: Biblioteca Nueva.

Dellinger, M. A. (2014). The Mythopoeia of Dolores Ibarruri, Pasionaria. En A. G.

Morcillo (ed.). Memory and Cultural History of the Spanish Civil War. Realms of Oblivion (pp. 285-319). Leiden-Boston: Brill Publishers.

Elorza, A. y Bizcarrondo, M. (1999). Queridos camaradas. La Internacional Comunista y España, 1919-1939. Barcelona: Planeta.

Falcón I. (1996). Asalto a los cielos. Madrid: Temas de Hoy. 
García Castillejo, A. I. (1995). En el Parlamento y en la calle Dolores Ibárruri diputada. Madrid: Fundación Dolores Ibárruri.

Ginard i Féron, D. (2013). «La madre de todos los camaradas». Dolores Ibárruri como símbolo movilizador, de la Guerra Civil a la transición posfranquista. Ayer, 90 (2), 189-216.

Gruber, H. y Graves, P. (1998). Women and Socialism. Socialism and Women, Europe Between the Two World Wars. Oxford: Berghahn.

Hamilton, C. (2001). Activism and Representations of Motherhood in the Autobiography of Dolores Ibárruri, Pasionaria. Journal of Romance Studies, 1 (1), 17-25. Disponible en: http://dx. doi. org/10. 3167/147335301782485270

Herrmann, G. (1998). The Hermetic Goddess: Dolores Ibárruri as Text. Letras Peninsulares, 11, 181-206.

Ibárruri, D. (1932). Al camarada Hurtado y a todo el Partido, Mundo obrero, 5 de diciembre.

- (1934). Carta manuscrita, 9 de enero, Archivo Histórico del PCE, R-VI.

(1935). Escrito autobiográfico, Archivo Histórico del PCE 13/1. 1.

(1936). Nuestra Camarada «Pasionaria», Comandante honoraria del V Regimiento de Milicias Populares. Joven Guardia, 35, 6 de octubre.

- (1936a). Tres alocuciones de Pasionaria, Archivo Histórico del PCE R-VI.

- (1938). Discurso de nuestra camarada Pasionaria, Archivo Histórico del PCE R-VI.

- (1972) [1962]: El único camino. Moscú: Editorial Progreso.

Low, R. (1992). La Pasionaria: The Spanish Firebrand. London: Hutchinson.

Llona, M. (2014). From Militia Woman to Emakume: Myths Regarding Femininity during the Civil War in the Basque Country. En A. G. Morcillo (ed.). Memory and Cultural History of the Spanish Civil War. Realms of Oblivion (pp. 179-213). Leiden-Boston: Brill Publishers.

Maestro, A. y Carrillo, S. (2004). Dolores Ibárruri, Pasionaria. Barcelona: Ediciones B.

Mangini, S. (1997). Recuerdos resistencia: la voz de las mujeres de la Guerra Civil española. Barcelona: Península.

Moreno Seco, M. (2015). Parti communiste et féminisme en Espagne. Vingtième Siècle Revue d'Histoire, 126, 133-146. Disponible en: http://dx. doi. org/10. 3917/ving. 126.0133

Mosse, G. L. (2001). La imagen del hombre. Madrid: Talasa.

Nash, M. (1981). Mujer y movimiento obrero en España, 1931-1939. Barcelona: Editorial Fontamara.

- (1999). Rojas. Las mujeres republicanas en la Guerra Civil. Madrid: Taurus.

- (2008). Mujeres en guerra: repensar la historia. En J. Casanova Ruiz, y P. Preston (ed.). La guerra civil española (pp. 61-84). Madrid: Editorial Pablo Iglesias.

Núñez Seixas, X. M. (2006). Fuera el invasor, nacionalismos y movilización bélica en la Guerra Civil española. Madrid: Marcial Pons.

Pamiés, T. (1977). Una española llamada Dolores Ibárruri. Barcelona: Martínez Roca. 
Radclyff, P. B. (1997). La representación de la nación: el conflicto en torno a la identidad nacional y las prácticas simbólicas en la Segunda República. En R. Cruz y M. Pérez Ledesma (ed.). Cultura y movilización en la España contemporánea (pp. 305-325). Madrid: Alianza Editorial.

Ramos, M. D. (2005). La república de las librepensadoras (1890-1914): laicismo, emancipismo, anticlericalismo. Ayer, 60 (4), 45-74.

Ripa, Y. (1997). Le mythe de Dolores Ibárruri. Clio. Femmes, Genre, Histoire, 5, 2-6. Disponible en: http://dx. doi. org/10. 4000/clio. 414

Scanlon, G. (1986). La polémica feminista en España. Madrid: Akal.

Tavera, S. (2005). La memoria de las vencidas. Ayer, 60 (4), 197-224.

Vázquez Montalbán, M. (1995). Pasionaria y los siete enanitos. Barcelona: Planeta.

Yusta, M. (2009). Madres coraje contra Franco. Madrid: Cátedra.

(2011). La construcción de una cultura política femenina desde el antifascismo (1934-1950). En A. Aguado y T. M. Ortega. Feminismos y antifeminismos. Culturas políticas e identidades de género en la España del siglo XX (pp. 258-266). Valencia: PUV. 
